\title{
Bismuth nitrate-induced microwave-assisted expeditious synthesis of vanillin from curcumin
}

\author{
Debasish Bandyopadhyay and Bimal K Banik
}

\begin{abstract}
Background: Curcumin and vanillin are the two useful compounds in food and medicine. Bismuth nitrate pentahydrate is an economical and ecofriendly reagent.

Method: Bismuth nitrate pentahydrate impregnated montmorillonite KSF clay and curcumin were subjected to microwave irradiation.

Results: Microwave-induced bismuth nitrate-promoted synthesis of vanillin from curcumin has been accomplished in good yield under solvent-free condition. Twenty-five different reaction conditions have been studied to optimize the process.

Conclusion: The present procedure for the synthesis of vanillin may find useful application in the area of industrial process development.
\end{abstract}

Keywords: Curcumin, Vanillin, Microwave, Bismuth nitrate, Fragrance

\section{Background}

Curcumin, a polyphenol derived from Curcuma longa (commonly known as turmeric) is an ancient spice and therapeutic used in India for centuries to induce color in food and to treat a wide array of diseases. It has been demonstrated that curcumin has many beneficial pharmacological effects, including anti-inflammatory [1], antioxidant [2], antiviral [3], antiangiogenic [4] effects. Most importantly, curcumin possesses immense antitumorigenic effect. It prevents tumor formation in a number of animal models, including models of skin, colon, liver, esophageal, stomach, and breast cancer [5-8]. Curcumin has also demonstrated the ability to improve patient outcomes in Phase I clinical trials [9]. The potential application of curcumin as a chemopreventive agent in both animal and human studies has been demonstrated [10]. Very recently, curcumin has been reported [11] as a protectant against neurodegenerative diseases through chelation with iron. On the other hand, vanillin (4-hydroxy-3-methoxybenzaldehyde) is an important guaiacol derivative which is extremely selective inhibitor of aldehyde oxidase. It has been found that it acts as a substrate of this enzyme, and is metabolized by aldehyde dehydrogenase [12]. Because of the exceptionally widespread utilization of vanillin in the food, cosmetic, pharmaceutical, nutraceutical and fine chemical industries makes this compound as one of the most important aromas. As a result of these crucial properties, considerable attention has been devoted to the improvement of the production processes of vanillin [13]. We report herein an easy and extremely rapid one-step method for the preparation of vanillin from naturally occurring curcumin in the presence of bismuth nitrate under microwave irradiation (Figure 1).

\section{Methods}

FT-IR spectra were registered on a Bruker IFS 55 Equinox FTIR spectrophotometer as $\mathrm{KBr}$ discs. ${ }^{1} \mathrm{H}$ NMR (300 MHz) and ${ }^{13} \mathrm{C}$ NMR $(75 \mathrm{MHz})$ spectra were obtained at room temperature with JEOL-300 equipment using $\mathrm{d}_{6}$-DMSO as solvent. Analytical grade chemicals (Sigma-Aldrich Corporation, Milwaukee, USA) were used throughout the project. Deionized water was used for the preparation of all aqueous solutions.

\footnotetext{
* Correspondence: banik@utpa.edu

Department of Chemistry, The University of Texas-Pan American, 1201 West University Drive, Edinburg, TX 78539, USA
} 


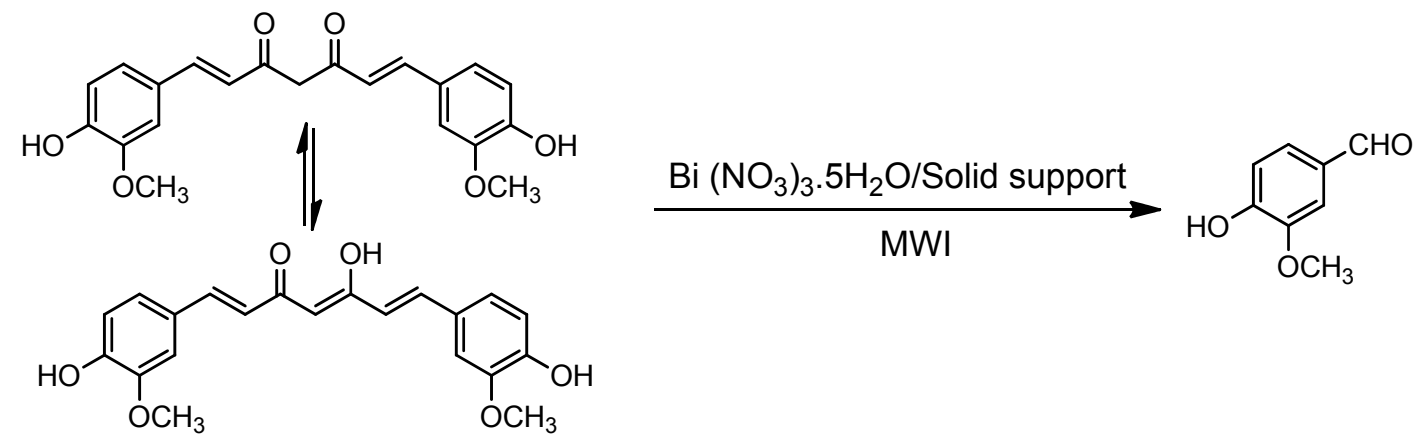

Figure 1 Bismuth nitrate pentahydrate-induced simple synthesis of vanillin from curcumin under microwave irradiation.

\section{Results and discussion}

In continuation of our research on environmentally benign reactions, we have been working on methodology development using microwave irradiation for many years. Using microwave irradiation technique, we have successfully developed several new organic methodologies which include stereoselective synthesis of $\beta$-lactams [14-16], synthesis of pyrroles [17-20], aza-Michael addition [21], and synthesis of quinoxalines [22]. On the other hand, we have demonstrated the catalytic activity of trivalent bismuth nitrate pentahydrate in a number of occasions. These experiments resulted in various methods that include nitration of aromatic systems [23-25], Michael reaction [26], protection of carbonyl compounds [27], deprotection of oximes and hydrazones [28], Paal-Knorr synthesis of pyrroles [29], hydrolysis of amide [30], electrophilic substitution of indoles [31,32], synthesis of $\alpha$ aminophosphonates [33], and Biginelli condensation [34]. Our success in the bismuth nitrate-induced reaction has confirmed that this reagent acts as a Lewis acid. Bismuth nitrate pentahydrate is proved to be an effective reagent for the preparation of vanillin. However, $\mathrm{Zn}\left(\mathrm{NO}_{3}\right)_{2}, \mathrm{Ca}$ $\left(\mathrm{NO}_{3}\right)_{2}, \mathrm{LaNO}_{3}, \mathrm{NaNO}_{3}$, ceric ammonium nitrate, and $\mathrm{Cu}\left(\mathrm{NO}_{3}\right)_{2}$ were also studied but without any success. Dry conditions and solvent-free methods along with commercial solvents without any purification were investigated in order to identify the best conditions for this reaction (Table 1). Reactions were performed at high temperature using Dean-Stark water separator, traditional reflux, and conventional kitchen microwave-induced methods. Solid surfaces such as florisil, silica gel, molecular sieves, montmorillonite KSF clay, and neutral alumina were used as solid support in the reaction. It has been found that montmorillonite KSF clay is the best solid surface (entries 4, 9, and 19) among all others.

\section{Experimental}

Curcumin ( $1 \mathrm{mmol})$, bismuth nitrate pentahydrate $(0.75$ equivalent), and solid support (500 $\mathrm{mg}$ ) were mixed in dichloromethane $(4 \mathrm{~mL})$ and the solvent was evaporated by rotavapor. The mixture was irradiated in kitchen microwave and the reaction was monitored by TLC. After completion of the reaction (Table 1), the reaction mixture was extracted with dichloromethane and basified with saturated aqueous sodium bicarbonate solution. The organic layer was then washed with brine and

Table 1 Bismuth nitrate pentahydrate-induced simple synthesis of vanillin from curcumin following Figure 1

\begin{tabular}{llll}
\hline Entry & Solid surface & Method/solvent & Yield (\%) \\
\hline 1 & Florisil & Dean-Stark/Benzene & NR \\
2 & Silica gel & Dean-Stark/Benzene & NR \\
3 & Molecular sieves & Dean-Stark/Benzene & NR \\
4 & KSF clay & Dean-Stark/Benzene & 10 \\
5 & Neutral alumina & Dean-Stark/Benzene & NR \\
6 & Florisil & Reflux/DCM & NR \\
7 & Silica gel & Reflux/DCM & NR \\
8 & Molecular sieves & Reflux/DCM & NR \\
9 & KSF clay & Reflux/DCM & 34 \\
10 & Neutral alumina & Reflux/DCM & 15 \\
11 & Florisil & Dry & NR \\
12 & Silica gel & Dry & NR \\
13 & Molecular sieves & Dry & NR \\
14 & KSF clay & Dry & NR \\
15 & Neutral alumina & Dry & NR \\
16 & Florisil & Microwave/solvent free & 60 \\
17 & Silica gel & Microwave/solvent free & 54 \\
18 & Molecular sieves & Microwave/solvent free & 45 \\
19 & KSF clay & Microwave/solvent free & 77 \\
20 & Neutral alumina & Microwave/solvent free & 61 \\
21 & Florisil & Reflux/Benzene & NR \\
22 & Silica gel & Reflux/Benzene & NR \\
23 & Molecular sieves & Reflux/Benzene & NR \\
24 & KSF clay & Reflux/Benzene & NR \\
25 & Neutral alumina & Reflux/Benzene & NR \\
\hline
\end{tabular}

a No reaction

${ }^{b}$ Without microwave irradiation, room temperature 
water successively, dried with anhydrous sodium sulfate. The pure product $(77 \%)$ was isolated by flash chromatography over silica gel.

\section{4-hydroxy-3-methoxybenzaldehyde (vanillin)}

Light yellow crystals; Mp: $82-83^{\circ} \mathrm{C}$, IR ( $\mathrm{KBr}$ disk, $\left.\mathrm{cm}^{-1}\right)$ : $3176,1679,1597,1512,1426,1385,1112,814,710 ;{ }^{1}$ H NMR (d d $\left.^{-D M S O}, 300 \mathrm{MHz}\right) \delta: 9.86(\mathrm{~s}, 1 \mathrm{H}), 8.09(\mathrm{~m}$, $2 \mathrm{H}), 7.57$ (s, $1 \mathrm{H}), 3.96(\mathrm{~s}, 1 \mathrm{H}) .{ }^{13} \mathrm{C}$ NMR $\left(\mathrm{d}_{6}\right.$-DMSO, $75 \mathrm{MHz}) \delta: 190.98,151.33,148.08,137.57,128.28,121.47$, 113.05, and 57.34.

\section{Conclusions}

In summary, a new and simple method for the synthesis of vanillin from naturally occurring curcumin has successfully been investigated. Trivalent bismuth nitrateinduced synthesis of vanillin has successfully been carried out under various conditions and the formation of a single product (4-hydroxy-3-methoxybenzaldehyde) has been observed in variable yields. The exploratory results described herein confirm that bismuth nitrate pentahydrate is the reagent of choice for the oxidative cleavage of curcumin to vanillin in the absence of any solvent under microwave-irradiation condition (entry 19). Importantly, no aromatic nitration and rearrangement of curcumin or vanillin has been observed with bismuth nitrate. A selective oxidation of the alkene bond of curcumin to vanillin has taken place. Considering the structure of vanillin and the conditions of the experiments, one can expect further oxidation of the aromatic aldehyde group or nitration of the aromatic system might be other possibilities. However, it is interesting to note that such reactions although feasible, but vanillin is the only isolated product. On the basis of these important and selective observations, this method will find very useful applications in industrial chemistry.

\section{Acknowledgements}

We gratefully acknowledge the funding support from the NIH-SCORE (Grant \# 2S06M008038-37).

\section{Authors' contributions}

DB performed the reactions and structure elucidation of the product. All authors read and approved the final manuscript.

\section{Competing interests}

The authors declare that they have no competing interests.

Received: 3 January 2012 Accepted: 20 April 2012

Published: 20 April 2012

\section{References}

1. Srivastava R, Srimal RC (1985) Modification of certain inflammationinduced biochemical changes by curcumin. Ind J Med Res 81:215-223

2. Ruby AJ, Kuttan G, Babu KD, Rajasekharan KN, Kuttan R (1995) Anti-tumour and antioxidant activity of natural curcuminoids. Cancer Lett 94:79-83. doi:10.1016/0304-3835(95)03827-J.
3. Li CJ, Zhang LJ, Dezube BJ, Crumpacker CS, Pardee AB (1993) Three inhibitors of type 1 human immunodeficiency virus long terminal repeatdirected gene expression and virus replication. Proc Natl Acad Sci USA 90:1839-1842. doi:10.1073/pnas.90.5.1839.

4. Aggarwal BB, Kumar A, Bharti AC (2003) Anticancer potential of curcumin: preclinical and clinical studies. Anticancer Res 23:363-398

5. Chuang SE, Kuo ML, Hsu CH, Chen CR, Lin JK, Lai GM, Hsieh CY, Cheng AL (2000) Curcumin-containing diet inhibits diethylnitrosamine-induced murine hepatocarcinogenesis. Carcinogenesis 21:331-335. doi:10.1093/carcin/ 21.2.331.

6. Ushida J, Sugie S, Kawabata K, Pham QV, Tanaka T, Fujii K, Takeuchi H, Ito Y, Mori $\mathrm{H}$ (2000) Chemopreventive effect of curcumin on $\mathrm{N}$ nitrosomethylbenzylamine-induced esophageal carcinogenesis in rats. Jpn J Cancer Res 91:893-898. doi:10.1111/j.1349-7006.2000.tb01031.x.

7. Kawamori T, Lubet R, Steele VE, Kelloff GJ, Kaskey RB, Rao CV, Reddy BS (1999) Chemopreventive effect of curcumin, a naturally occurring antiinflammatory agent, during the promotion/progression stages of colon cancer. Cancer Res 59:597-601

8. Huang MT, Newmark HL, Frenkel K (1997) Inhibitory effects of curcumin on tumorigenesis in mice. J Cell Biochem Suppl 27:26-34

9. Cheng AL, Hsu CH, Lin JK, Hsu MM, Ho YF, Shen TS, Ko JY, Lin JT, Lin BR, Ming-Shiang W, Yu HS, Jee SH, Chen GS, Chen TM, Chen CA, Lai MK, Pu YS, Pan MH, Wang YJ, Tsai CC, Hsieh CY (2001) Phase I clinical trial of curcumin, a chemopreventive agent, in patients with high-risk or pre-malignant lesions. Anticancer Res 21:2895-2900

10. Jiao Y, Wilkinson J, Pietsch EC, Buss JL, Wang W, Planalp R, Torti FM, Torti SV (2006) Iron chelation in the biological activity of curcumin. Free Rad Biol Med 40:1152-1160. doi:10.1016/j.freeradbiomed.2005.11.003.

11. Minear S, O'Donnell AF, Ballew A, Giaever G, Nislow C, Stearns T, Cyert MS (2011) Curcumin inhibits growth of Saccharomyces cerevisiae through iron chelation. Eukaryot Cell 10:1574-1581. doi:10.1128/EC.05163-11.

12. Panoutsopoulos G, Beedham C (2005) Enzymatic oxidation of vanillin, isovanillin and protocatechuic aldehyde with freshly prepared guinea pig liver slices. Cell Physiol Biochem 15:89-98. doi:10.1159/000083641.

13. Korthou H, Verpoorte R (2007) Vanilla, flavours and fragrances, chap 9. Springer, Berlin pp 203-217

14. Bandyopadhyay D, Banik BK (2010) Microwave-induced stereoselectivity of B-lactam formation with dihydrophenanthrenyl imines via Staudinger cycloaddition. Helv Chim Acta 93:298-301. doi:10.1002/hlca.200900212.

15. Bandyopadhyay D, Yanez M, Banik BK (2011) Microwave-induced stereoselectivity of $\beta$-lactam formation: effects of solvents. Heterocycl Lett 1 (special issue, July):65-67

16. Bandyopadhyay D, Rivera G, Salinas I, Aguilar H, Banik BK (2010) lodinecatalyzed remarkable synthesis of novel $\mathrm{N}$-polyaromatic $\beta$-lactams bearing pyrroles. Molecules 15:1082-1088. doi:10.3390/molecules15021082.

17. Bandyopadhyay D, Mukherjee S, Banik BK (2010) An expeditious synthesis of $\mathrm{N}$-substituted pyrroles via microwave-induced iodine-catalyzed reaction under solventless conditions. Molecules 15:2520-2525. doi:10.3390/ molecules15042520.

18. Andoh-Baidoo R, Danso R, Mukherjee S, Bandyopadhyay D, Banik BK (2011) Microwave-induced $\mathrm{N}$-bromosuccinimide-mediated novel synthesis of pyrroles via Paal-Knorr reaction. Heterocycl Lett 1(special issue, July):107-109

19. Bandyopadhyay D, Banik A, Bhatta S, Banik BK (2009) Microwave-assisted ruthenium trichloride catalyzed synthesis of pyrroles fused with indole systems. Heterocycl Commun 15:121-122

20. Abrego D, Bandyopadhyay D, Banik BK (2011) Microwave-induced indiumcatalyzed synthesis of pyrrole fused with indolinone in water. Heterocycl Lett 1:94-95

21. Kall A, Bandyopadhyay D, Banik BK (2010) Microwave-induced aza-Michael reaction in water: a remarkable simple procedure. Synth Commun 42:1730-1735

22. Bandyopadhyay D, Mukherjee S, Rodriguez RR, Banik BK (2010) An effective microwave-induced iodine-catalyzed method for the synthesis of quinoxalines via condensation of 1,2-dicarbonyl compounds. Molecules 15:4207-4212. doi:10.3390/molecules15064207.

23. Canales L, Bandyopadhyay D, Banik BK (2011) Bismuth nitrate pentahydrateinduced novel nitration of Eugenol. Org Med Chem Lett 1:9. doi:10.1186/ 2191-2858-1-9. 
24. Banik BK, Samajdar S, Banik I, Ng S, Hann J (2003) Montmorillonite impregnated with bismuth nitrate: microwave-assisted facile nitration of $\beta$ lactams. Heterocycles 61:97-100. doi:10.3987/COM-03-S62.

25. Bose A, Sanjoto WP, Villarreal S, Aguilar H, Banik BK (2007) Novel nitration of estrone by metal nitrates. Tetrahedron Lett 48:3945-3947. doi:10.1016/j. tetlet.2007.04.050.

26. Srivastava N, Banik BK (2003) Bismuth nitrate-catalyzed versatile Michael reactions. J Org Chem 68:2109-2114. doi:10.1021/j0026550s.

27. Srivastava N, Dasgupta SK, Banik BK (2003) A remarkable bismuth nitratecatalyzed protection of carbonyl compounds. Tetrahedron Lett 44:1191-1193. doi:10.1016/50040-4039(02)02821-6.

28. Banik BK, Adler D, Nguyen P, Srivastava N (2003) A new bismuth nitrateinduced stereospecific glycosylation of alcohols. Heterocycles 61:101-104. doi:10.3987/COM-03-S63.

29. Rivera S, Bandyopadhyay D, Banik BK (2009) Facile synthesis of Nsubstituted pyrroles via microwave-induced bismuth nitrate-catalyzed reaction under solventless conditions. Tetrahedron Lett 50:5445-5448. doi:10.1016/j.tetlet.2009.06.002.

30. Bandyopadhyay D, Fonseca RS, Banik BK (2011) Microwave-induced bismuth nitrate-mediated selective hydrolysis of amide. Heterocycl Lett 1 (special issue, July):75-77

31. Iglesias L, Aguilar C, Bandyopadhyay D, Banik BK (2010) A new bismuth nitrate-catalyzed electrophilic substitution of indoles with carbonyl compounds under solventless conditions. Synth Commun 40:3678-3682. doi:10.1080/00397910903531631.

32. Rivera S, Bandyopadhyay D, Banik BK (2011) Microwave-induced bismuth nitrate-catalyzed electrophilic substitution of 7-aza indole with activated carbonyl compound under solvent-free conditions. Heterocycl Lett 1(special issue, July):43-46

33. Banik A, Bhatta S, Bandyopadhyay D, Banik BK (2010) A highly efficient bismuth salts-catalyzed route for the synthesis of a-aminophosphonates. Molecules 15:8205-8213. doi:10.3390/molecules15118205.

34. Banik BK, Reddy AT, Datta A, Mukhopadhyay C (2007) Microwave-induced bismuth nitrate-catalyzed synthesis of dihydropyrimidones via Biginelli condensation under solventless conditions. Tetrahedron Lett 48:7392-7394. do::10.1016/j.tetlet.2007.08.007.

doi:10.1186/2191-2858-2-15

Cite this article as: Bandyopadhyay and Banik: Bismuth nitrate-induced microwave-assisted expeditious synthesis of vanillin from curcumin.

Organic and Medicinal Chemistry Letters 2012 2:15.

\section{Submit your manuscript to a SpringerOpen ${ }^{\circ}$ journal and benefit from:}

- Convenient online submission

- Rigorous peer review

- Immediate publication on acceptance

- Open access: articles freely available online

- High visibility within the field

- Retaining the copyright to your article

Submit your next manuscript at $\gg$ springeropen.com 